\title{
UPAYA SUSTAINABILITAS UKM SUSU MELALUI PENGENDALIAN KUALITAS KANDUNGAN KADAR LEMAK SUSU MENGGUNAKAN STATISTICAL QUALITY CONTROL METHOD
}

\author{
Debrina Puspita Andriani ${ }^{1)}$, Firda Rahmatika ${ }^{2)}$, Medi Susanto ${ }^{3)}$ \\ 1),2),3 ) Teknik Industri, Universitas Brawijaya
}

\begin{abstract}
Abstrak . Berdasarkan dari data Badan Pusat Statistik (BPS) diketahui bahwa volume produksi susu dari seluruh perusahaan di Indonesia mengalami kenaikan dari tahun ke tahun, sehingga dapat diketahui bahwa adanya peningkatan akan permintaan susu dari konsumen. Dengan adanya hal tersebut, maka perusahaan saling bersaing untuk menghasilkan produk susu dengan spesifikasi komposisi nutrisi yang sangat beragam dan semakin komplek dengan tujuan untuk memenuhi kebutuhan konsumen, termasuk pada salah satu UKM produsen susu yang terletak di Kabupaten Malang. Penelitian ini bertujuan untuk menentukan apakah salah satu kandungan nutrisi susu, yaitu kadar lemak pada susu, masih berada dalam batas spesifikasi produk dan menganalisis faktor-faktor yang dapat menyebabkan kandungan kadar lemak tidak sesuai dengan spesifikasi. Data yang digunakan merupakan data dari kandungan kadar lemak susu yang diperoleh setelah melakukan pengujian kualitas kandungan kadar lemak dengan menggunakan 5 sampel setiap harinya dari 32 pos penampungan susu selama 30 hari. Berdasarkan hasil dari peta kendali variabel yaitu peta kendali rata-rata (x) diketahui masih terdapat data yang berada di luar batas kendali, sedangkan dari hasil peta kendali jarak (r) semua data berada di dalam batas kendali. Dari hasil tersebut dilakukan revisi terhadap kedua peta agar semua data dapat masuk di dalam batas kendali. Tahap selanjutnya dilakukan analisis akar penyebab masalah berdasarkan hasil brainstorming dengan pemilik usaha dan digambarkan menggunakan fishbone diagram. Faktor-faktor yang ditinjau meliputi manusia, bahan baku, metode, dan lingkungan. Tahap terakhir dilakukan perumusan usulan perbaikan yang diharapkan dapat mengurangi jumlah susu dengan kandungan kadar lemak yang tidak sesuai dengan spesifikasi, sehingga juga dapat membantu keberlanjutan (sustainability) usaha.
\end{abstract}

Kata Kunci: Analisis Kemampuan Proses, Fishbone Diagram, Kadar Lemak Susu, Pengendalian Kualitas, Peta Kendali.

Persaingan di dunia industri yang makin kompetitif menyebabkan banyaknya unit usaha dan industri baru yang bermunculan terutama yang bergerak di bidang customer goods [1]. Salah satu produk yang yang biasa dihasilkan oleh industri yang bergerak dibidang customer goods adalah produk susu. Berdasarkan data dari Badan Pusat Statistik (BPS) diketahui bahwa volume produksi susu dari seluruh produsen di Indonesia mengalami kenaikan dari tahun ke tahun. Grafik dari peningkatan produksi susu ini dapat dilihat pada Gambar 1 . Dengan adanya peningkatan volume produksi susu di Indonesia yang tinggi, maka dapat diketahui bahwa kebutuhan ataupun permintaan produksi susu dari konsumen juga mengalami peningkatan. Dengan adanya hal tersebut, maka tidak bisa dipungkiri para produsen susu saling bersaing untuk menghasilkan produk susu dengan komposisi nutrisi yang sangat beragam dan semakin komplek dengan tujuan untuk memenuhi kebutuhan konsumen, termasuk yang terjadi pada tempat studi kasus yang merupakan salah satu UKM produsen susu di Kabupaten Malang, Indonesia. Untuk menghadapi persaingan dibutuhkan strategi atau langkah sistematis yang dapat membantu unit usaha ini agar tetap dapat terus bertahan [2]. 


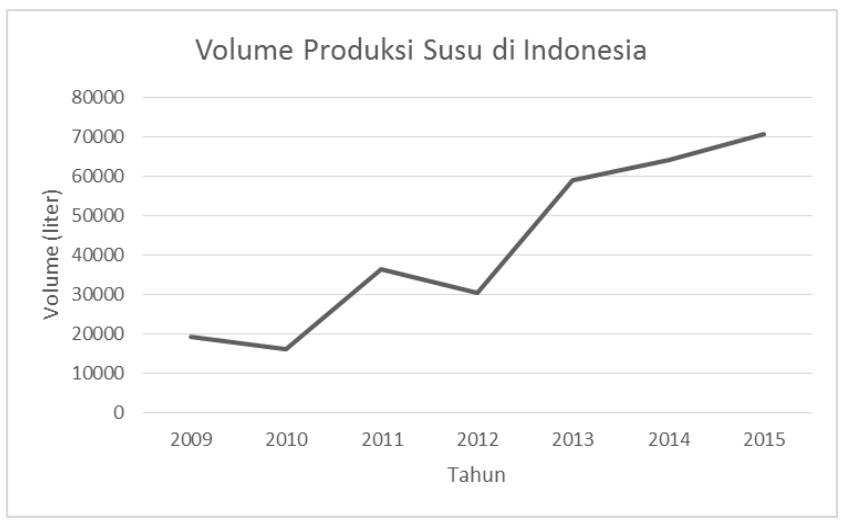

Gambar 1. Volume produksi susu di Indonesia

Salah satu strategi yang dapat diterapkan oleh UKM ini adalah melalui kegiatan pengendalian kualitas. Namun hal yang perlu diperhatikan tidak hanya kualitas dari produk susu yang dihasilkan oleh perusahaan, tetapi juga kualitas dari bahan baku susu yang dihasilkan oleh pemasok bahan baku susu, yaitu para peternak. Untuk menghasilkan kualitas susu yang baik dan konsisten dari peternak dibutuhkan suatu metode dalam mengendalikan kualitas bahan baku susu agar sesuai dengan kualitas yang ingin dicapai. Pengendalian kualitas dari produk susu yang dihasilkan oleh peternak tentunya sangat dibutuhkan, karena hanya susu yang memiliki kualitas sesuai dengan spesifikasi yang akan dijual ke pelanggan dan didistribusikan ke perusahaan-perusahaan yang lainnya.

Saat ini UKM telah melaksanakan uji kualitas di laboratorium untuk susu yang diterima dari para peternak [3]. Uji tersebut meliputi uji pemalsuan susu dengan menggunakan alkohol, uji sukrosa, uji antibiotik, uji berat jenis, uji MBRT (Methyl Blue Reduction Time), uji kadar lemak, uji rasa, uji bau, dan uji warna yang nantinya dapat membantu dalam penentuan kriteria susu. Kualitas yang diperhatikan oleh pihak UKM adalah kualitas nutrisi yang ada di susu, seperti berat jenis, kadar lemak, kandungan antibotik, sukrosa, aktifitas mikroba, dan keaslian susu. Diantara semua uji kualitas susu yang dilakukan, salah satu uji yang penting adalah uji kandungan kadar lemak susu. Berdasarkan hasil pengujian kandungan kadar lemak susu dapat diketahui nantinya berpengaruh terhadap penggolongan kualitas susu dan harga jual susu. Kandungan kadar lemak yang rendah dapat menyebabkan harga jual susu menjadi rendah, demikian pula sebaliknya.

Meskipun telah dilakukan uji kualitas di laboratorium, akan tetapi selama ini UKM belum menerapkan metode pengendalian kualitas untuk mengukur kondisi dari hasil uji kualitas susu peternak apakah telah sesuai dengan spesifikasi atau tidak. Sering kali masih ditemukan produk susu yang telah selesai diproduksi oleh UKM dan dikirim ke perusahaan tidak diterima karena belum sesuai dengan spesifikasi produk yang diharapkan. Oleh karena itu, melalui penelitian ini diusulkan penggunaan metode pengendalian kualitas untuk mengetahui spesifikasi susu peternak yang diterima selama ini, sehingga diharapkan nantinya dapat meningkatkan kualitas dan harga jual dari susu tersebut.

Pengendalian kualitas merupakan aktivitas teknik dan manajemen dengan melakukan pengukuran karakteristik kualitas dari output kemudian dibandingkan dengan hasil spesifikasi output yang diinginkan oleh pelanggan/konsumen [4]. Pengendalian kualitas juga dikatakan sebagai usaha untuk mempertahankan mutu atau kualitas dari barang yang dihasilkan, agar sesuai dengan spesifikasi produk yang telah ditetapkan berdasarkan kebijaksanaan pimpinan perusahaan [5]. Tujuan dari pengendalian kualitas adalah agar barang hasil produksi dapat mencapai standar kualitas yang telah ditetapkan, biaya inspeksi, biaya desain dari produk dan proses, serta biaya produksi menjadi serendah mungkin [6]. Terdapat beberapa faktor yang mempengaruhi pengendalian kualitas yang dilakukan perusahaan yaitu kemampuan proses, spesifikasi yang berlaku, tingkat ketidaksesuaian yang dapat diterima, dan biaya 
kualitas [7]. Dengan menerapkan pengendalian kualitas, maka diharapkan dapat dianalisis penyebab variasi atau penyimpangan yang terjadi untuk perbaikan sistem produksi selanjutnya $[8,9]$.

\section{METODE}

Pengumpulan data kandungan kadar lemak susu diperoleh dari arsip perusahaan yang dilakukan oleh unit persusuan bagian laborat. Data yang diambil sebanyak 5 sampel dan diperoleh dari 32 Pos Penampungan Susu di UKM Susu selama 30 hari. Penelitian ini menggunakan 3 metode dalam pengumpulan data, yaitu observasi, wawancara, dan dokumentasi.

Analisa mengenai pengendalian kualitas yang dilakukan pada penelitian ini yaitu dengan membuat peta kendali atau control chart. Control Chart adalah suatu alat yang digunakan untuk memonitor atau mengevaluasi suatu aktivitas atau proses masih dalam batas pengendalian kualitas secara statistik atau tidak, sehingga dapat memecahkan masalah dan menghasilkan perbaikan kualitas [10]. Terdapat beberapa jenis peta kendali, salah satunya adalah peta kendali rata-rata $(\mathrm{X})$ dan jarak (R) yang merupakan peta kendali variabel [11]. Peta kendali rata-rata dan jarak merupakan dua peta pengendali yang saling membantu dalam mengambil keputusan mengenai kualitas proses. Peta kendali ratarata merupakan peta kendali untuk melihat apakah proses masih berada dalam batas pengendali atau tidak. Proses produksi dikatakan baik apabila produk yang dihasilkan berada disekitar garis pusat (center line). Namun data yang berada di luar batas pengendali statistik apabila dikarenakan suatu sebab umum (sebab yang melekat pada proses) maka tidak boleh dihilangkan dan dianggap tetap masuk batas pengendali. Sementara data yang berada diluar batas pengendali rata-rata disebut sebagai (out of statistical control) yang disebabkan oleh sebab khusus [12].

Peta kendali digunakan untuk membantu mendeteksi adanya penyimpangan dengan cara menetapkan batas-batas kendali, meliputi batas kendali atas atau upper control limit (UCL), batas kendali bawah atau lower control limit $(L C L)$, dan garis tengah atau center line (CL). UCL dan LCL masing-masing merupakan garis batas kendali atas dan bawah untuk suatu penyimpangan yang masih diperbolehkan.
Sedangkan CL merupakan garis yang menunjukkan tidak adanya penyimpangan dari sampel. Tahap awal adalah perhitungan batas kendali atas (upper control limit/UCL) dan batas kendali bawah (lower control limit/LCL) menggunakan data kandungan kadar lemak susu yang didapatkan dari hasil pengujian kadar lemak susu. Nilai CL, UCL, dan LCL digunakan pada peta kendali rata-rata (X) dan peta kendali jarak (R) untuk mengetahui berapa banyak data kandungan kadar lemak susu yang masih berada dalam batas kendali maupun yang di luar batas kendali. Setelah semua data sudah berada dalam batas kendali, maka nantinya akan dilakukan penghitungan analisis kemampuan proses (capability process $/ \mathrm{Cp}$ ) yang berfungsi untuk mengetahui kapabilitas dari proses tersebut. Selanjutnya dilakukan analisis penyebab adanya data yang diluar dari batas kendali dengan menggunakan fishbone diagram [13].

\section{HASIL DAN PEMBAHASAN}

\section{Analisis dengan Peta Kendali Variabel}

Untuk mengetahui kandungan kadar lemak sesuai dengan spesifikasi atau tidak maka dilakukan penghitungan dengan menggunakan peta kendali variabel dengan melakukan penghitungan berdasarkan pada rata-rata $(\mathrm{X})$ dan jarak (R). Peta kendali rata-rata merupakan peta pengendalian dengan memperhatikan harga rata-rata dari hasil (output) kerja. Variasi data akan diajukan dengan memperhatikan daerah sekitar garis sentral, sedangkan batasbatas kendali untuk peta ini digunakan Pers. (1) sampai dengan (3).

$$
\begin{aligned}
& \mathrm{UCL}=\bar{X}+A_{2} \times R . \\
& \mathrm{CL}=\bar{X} \ldots \ldots \ldots \ldots \ldots . \\
& \mathrm{LCL}=\bar{X}-A_{2} \times R .
\end{aligned}
$$

$A_{2}$ adalah suatu faktor yang nilainya akan tergantung pada jumlah data yang diambil dalam masing-masing banyaknya sampel (n) dan $\mathrm{R}$ adalah nilai rata-rata dari selisih nilai maksimum dan minimum dari data masingmasing banyaknya sampel.

Peta kendali jarak merupakan peta pengendalian dengan memperhatikan range atau selisih nilai maksimum dan minimum dari data output kerja. Variasi data juga akan ditujukan dengan memperhatikan daerah sekitar garis sentral yang dalam hal ini adalah nilai range rata-rata $(\mathrm{R})$, dan batas-batas 
kendali untuk peta $\mathrm{R}$ ini adalah pada Pers. (4) sampai dengan (6).

$$
\begin{aligned}
& \mathrm{UCL}=D_{4} \times \bar{R} \\
& \mathrm{CL}=\bar{R} \ldots \ldots \ldots \ldots \\
& \mathrm{LCL}=D_{3} \times \bar{R} .
\end{aligned}
$$

Proses kerja akan dikatakan terkendali apabila data yang diplotkan pada $\bar{X}$ ataupun $\mathrm{R}$ akan berada dalam batas-batas kendali. Apabila ada data yang keluar dari batas kendali yang ditetapkan meskipun hanya pada salah satu peta, maka proses kerja yang berlangsung perlu segera dianalisa dan dikoreksi. Pada dasarnya kedua peta $\bar{X}$ dan $\mathrm{R}$ harus dibuat secara bersama-sama sebelum kesimpulan bahwa proses terkendali atau tidaknya diambil [14].

Sebelum melakukan penghitungan mengenai CL, UCL dan LCL, maka dilakukan perhitungan mean dan range yang juga digunakan sebagai hasil penghitungan central line (CL). Persamaan (7) hingga (9) adalah sebagai berikut.

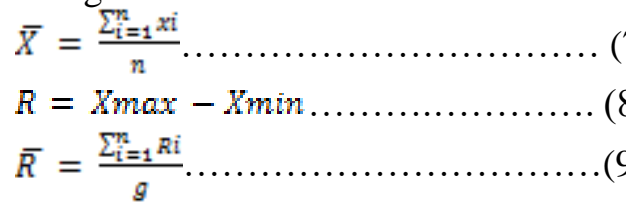

Langkah-langkah analisis dengan menggunakan X-R chart yaitu pertama dilakukan penghitungan nilai garis tengah atau center line pada peta kendali rata-rata $(\mathrm{X})$ maupun dengan peta kendali jarak (R) dengan menggunakan persamaan (7) dan (9). Berdsarkan penghitungan dengan persamaan tersebut didapatkan hasil nilai central line (CL) pada peta kendali rata-rata $(\mathrm{X})$ dan peta kendali jarak (R) berturut-turut adalah 40,15 dan 5,2. Selanjutnya menghitung batas kendali atas (UCL) dan batas kendali bawah (LCL) pada peta kendali rata-rata (X) dengan menggunakan persamaan (1) dan (3) didapatkan hasil secara berturut-turut yaitu 43,15 dan 37,15. Sedangkan nilai batas kendali atas (UCL) dan batas kendali bawah (LCL) pada peta kendali jarak (R) dengan menggunakan persamaan (4) dan (6) didapatkan hasil secara berturut-turut yaitu 10,99 dan 0 .

Setelah mendapatkan nilai garis tengah, batas kendali atas dan batas kendali bawah pada peta kendali rata-rata $(\mathrm{X})$ dan peta kendali jarak (R). Berdasarkan Gambar 2 didapatkan hasil bahwa pada peta kendali ratarata $(\mathrm{X})$ masih terdapat 1 data yang berada diluar batas kendali yaitu data pada observasi hari ke-24. Sedangkan pada peta kendali jarak (R) didapatkan bahwa semua data sudah berada dalam batas kendali. Oleh karena itu, dapat diketahui bahwa penyebab kandungan kadar lemak tidak sesuai spesifikasi disebabkan karena adanya variasi peyebab khusus, sehingga perlu dilakukannya revisi terhadap peta kendali rata-rata (X) dan jarak (R).

Oleh karena perlu dilakukannya revisi, maka dilakukan penghitungan ulang garis tengah, batas kendali atas dan batas kendali bawah tanpa menggunakan data yang keluar dari batas kendali yaitu data pada observasi hari ke-24 pada peta kendali rata-rata (X) dan peta kendali jarak (R). Setelah dilakukan revisi dan penghitungan ulang didapatkan hasil nilai garis tengah, batas kendali atas dan batas kendali bawah pada peta kendali rata-rata $(\mathrm{X})$ secara berturut-turut yaitu 40,33; 43,31; dan 37,35. Kemudian didapatkan hasil garis tengah, batas kendali atas dan batas kendali bawah pada peta kendali jarak (R) secara berturut-turut yaitu 5,17; 10,93 dan 0. Setelah dilakukan revisi didapatkan hasil bahwa semua data pada peta kendalui rata-rata $(\mathrm{X})$ dan peta kendali jarak $(\mathrm{R})$ sudah berada dalam batas kendali, sehingga tidak ada data yang outlier. Gambar 3 menunjukkan peta kendali yang sudah direvisi. 


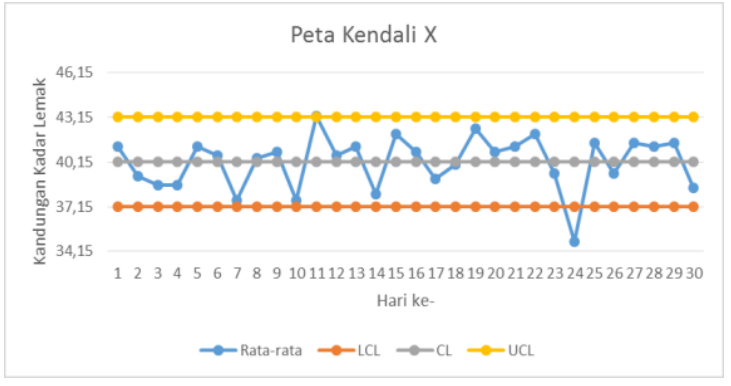

(a)

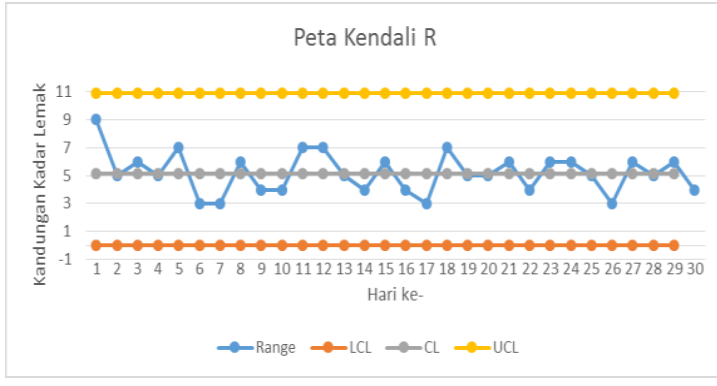

(b)

Gambar 2. Peta Kendali Kandungan Kadar Lemak: (a) X, (b) R

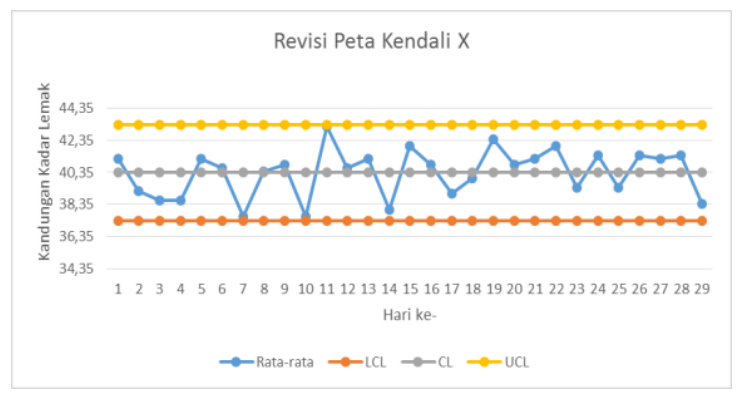

(a)

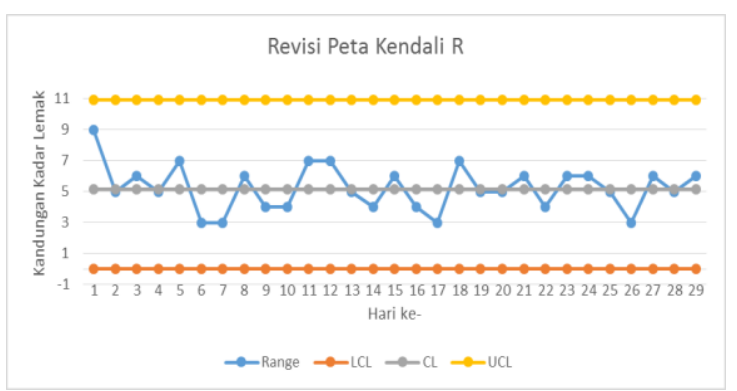

(b)

Gambar 3. Peta Kendali Kandungan Kadar Lemak yang Sudah Direvisi: (a) X, (b) R

\section{Analisa Kemampuan Proses (Capability Process/Cp)}

Analisis kemampuan proses (AKP) merupakan suatu studi guna menaksir kemampuan proses dalam bentuk distribusi probabilitas yang mempunyai bentuk, rerata dan penyebaran [15]. AKP mendefinisikan kemampuan proses memenuhi spesifikasi atau mengukur kinerja proses. Tujuan dilakukannya AKP adalah memprediksi variabilitas proses yang ada, menguji teori mengenai penyebab kesalahan selama program perbaikan kualitas, dan lainnya. Selanjutya alasan utama dalam mengkuantifikasi kemampuan proses untuk dapat berpegang pada spesifikasi produk [16]. Analisis kemampuan proses dilakukan pada kondisi in statistical control.

Apabila proses berada dalam batas pengendali statistik dengan peta pengendali proses statistik "normal" dan rata-rata proses terpusat pada target, maka rasio kemampuan proses atau indeks kemampuan proses dapat dihitung dengan menggunakan Pers. (10) dan (11). Dimana $\mathrm{Cp}$ adalah rasio kemampuan proses, USL adalah batas spesifikasi atas dan LSL adalah batas spesifikasi bawah yang ditetapkan konsumen dan harus dipenuhi oleh para produsen, serta $\sigma$ adalah standard deviasi proses. Dari hasil perhitungan tersebut, apabila nilai $\mathrm{Cp}>1$ berarti proses masih baik (capable), $\mathrm{Cp}<1$ berarti proses tidak baik (not capable), dan $\mathrm{Cp}=1$ berarti proses sama dengan spesifikasi konsumen. Semakin tinggi indeks kemampuan proses maka semakin sedikit produk yang berada di luar batas-batas spesifikasi.

$\mathrm{Cp}=U S L-L S L 6 \sigma$

$\sigma=\overline{R d} 2$

Selanjutnya dihitung nilai indeks kemampuan proses yang akan mewakili kemampuan sesungguhnya dari suatu proses dengan parameter nilai tertentu. Nilai Cpk diformulasikan dengan Persamaan (12).

$\mathrm{Cpk}=\min \{U S L-\mu 3 \sigma, \mu-L S L 3 \sigma\}$

$=\min \{\mathrm{Cpu}, \mathrm{Cpl}\}$

Langkah pertama yang dilakukan yaitu menghitung $\sigma$ dengan menggunakan persamaan (11) sehingga didapatkan nilai sebesar 2,22. Selanjutnya dilakukan pengitungan rasio kemampuan proses $(\mathrm{Cp})$ dengan menggunaan persamaan (10) sehingga didapatkan hasil sebesar 0,45. Setelah dilakukan penghitungan nilai $\mathrm{Cp}$, maka dilakukan penghitungan indeks kemampuan proses (Cpk) menggunakan persamaan (12) sehingga didapatkan hasil sebesar 0,45. 
Berdasarkan perhitungan $\mathrm{Cp}$ tersebut menunjukkan hasil sebesar $0,45<1$ maka dapat dikatakan bahwa proses tidak baik (not capable) serat rata-rata tidak terpusat. Sehingga menunjukkan bahwa proses tidak sesuai dengan spesifikasi konsumen. Sedangkan hasil dari penghitungan $\mathrm{Cpk}$ sebesar $0,45=$ nilai $\mathrm{Cp}$ sebesar 0,45. Maka dapat dikatakan bahwa nilai rata-rata yang sesungguhnya sama dengan central line. Jika semakin tinggi indeks kemampuan proses, maka semakin sedikit produk yang berada di luar batas-batas spesifikasi.

\section{Analisis Fishbone Diagram}

Berdasarkan analisis dengan menggunakan peta kendali rata-rata (X) dan jarak (R), diketahui masih terdapat data yang berada diluar batas kendali pada peta kendali rata-rata $(\mathrm{X})$, meskipun tidak terdapat data yang berada diluar batas kendali pada peta kendali jarak (R). Adanya penyebab khusus yang mengakibatkan data yang berada diluar batas kendali, maka untuk mengetahui faktor penyebab adanya data yang berada diluar batas kendali dilakukan analisis dengan menggunakan fishbone diagram [17].

Fishbone diagram disebut juga diagram sebab dan akibat (Ishikawa Diagram). Fishbone diagram digunakan untuk memahami penyebab masalah dan hubungan sebab akibat dari sebuah faktor penyebab permasalahan. Sehingga juga berguna dalam mengidentifikasi alternatif penyelesaian masalah. Faktor-faktor yang mempengaruhi hal tersebut yaitu faktor manusia, bahan baku, metode dan lingkungan [18].

Gambar 4 adalah fishbone diagram untuk mengetahui penyebab adanya data kandungan kadar lemak yang diluar batas spesifikasi. Dimana faktor-faktor tersebut merupakan hasil wawancara dengan pihak bagian dari anggota UKM Susu dan juga sebagai peternak susu sapi perah di daerah Ngantang serta brainstorming yang dilakukan secara langsung kepada pemilik usaha dan staff bagian Laborat Pengujian Kualitas. Berikut merupakan penjelasan untuk tiap-tiap faktor tersebut:

1. Faktor manusia yaitu dari peternak. Kesalahan dalam pemberian pakan ternak yaitu hijauan dan konsentrat yang tidak seimbang dapat menyebabkan adanya kandungan kadar lemak yang dibawah batasan yang diperbolehkan. Hal tersebut bisa terjadi karena kurangnya pelatihan atau sosialisasi kepada peternak mengenai hal terkait.

2. Faktor bahan baku yaitu kandungan susu yang diperah dari sapi perah merupakan hasil dari hijauan dan konsentrat yang diberikan oleh peternak. Oleh karena itu, pemberian hijauan dan konsentrat yang tepat sangat berpengaruh pada kandungan kadar lemak susu.

3. Faktor metode dalam memberikan konsentrat dan hijauan. Penyebab permasalahan pada faktor ini adalah tidak seimbangnya konsentrat dan hijauan yang diperikan oleh peternak, serta pemberian pakan yang tidak sesuai dengan kebutuhan dari sapi. Ketika jumlah hijauan yang diberikan pada sapi lebih banyak dibandingkan dengan jumlah konsentrat, maka dapat menyebabkan kandungan kadar lemak pada susu yang rendah, karena konsentrat merupakan nutrisi penting bagi sapi agar menghasilkan kualitas susu yang baik.

4. Faktor lingkungan yang dapat berpengaruh pada kandungan kadar lemak yaitu suhu lingkungan. Ketika suhu semakin meningkat, maka dapat menyebabkan sapi mengeluarkan banyak kalori. Sehingga dapat menyebabkan kadungan kadar lemak dapat menurun 


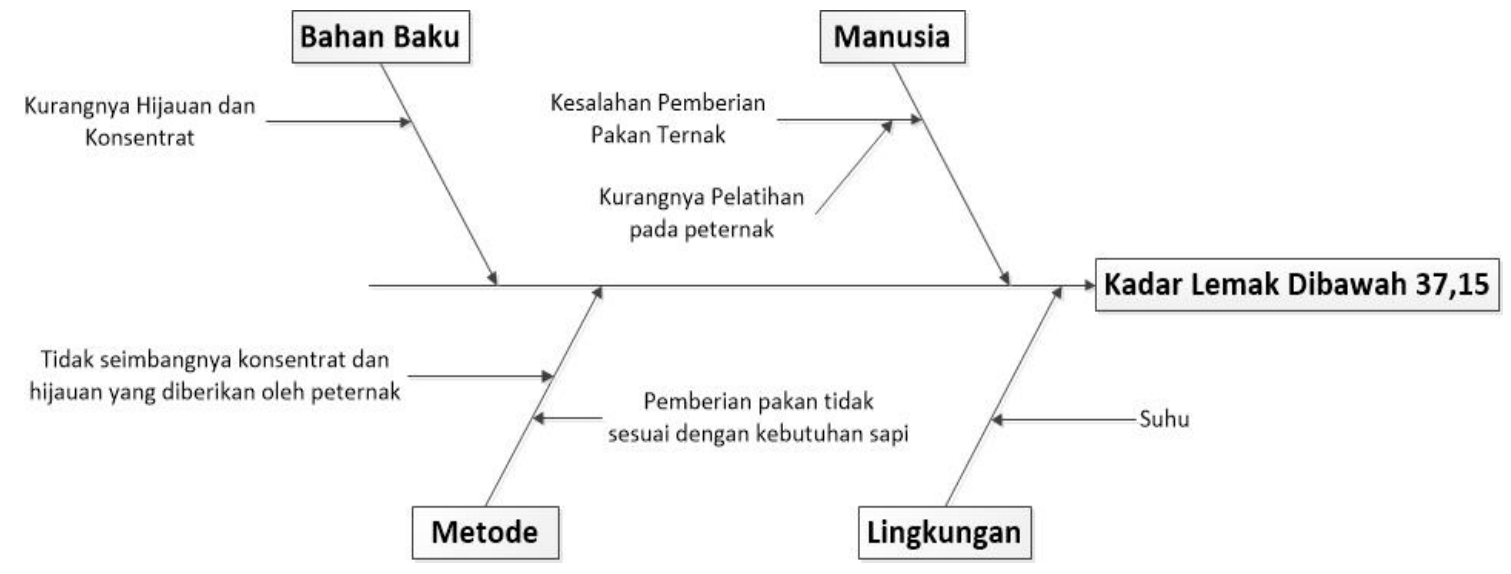

Gambar 4. Fishbone Diagram Kandungan Kadar Lemak

\section{Usulan Perbaikan}

Usulan perbaikan yang diberikan pada penelitian ini untuk mengurangi adanya kandungan kadar lemak susu yang diluar batas kendali atau standar. Peningkatan kualitas harus selalu dilakukan agar nantinya kandungan kadar lemak susu berada dalam batas kendali, namun solusi tersebut dengan cara memperbaiki dan mengontrol proses yang dilakuakn oleh petani agar nantinya dapat menghasilkan susu dengan kandungan kadar lemak yang sesuai dengan standar yaitu sebesar $37 \%$.

Usulan perbaikan yang didapatkan berdasarkan pada analisis dengan menggunakan diagram tulang ikan (fishbone diagram) untuk mengurangi adanya kandungan kadar lemak susu yang tidak sesuai dengan standar, maka didapatkan rekomendasi perbaikan sebagai berikut:

1. Faktor Manusia (Man) dengan memberikan sosialisasi atau pelatihan kepada peternak dari pihak UKM SUSU.

2. Faktor Bahan Baku (Material) dengan pihak peternak memiliki standard operating procedures dalam pemberian hijaun dan konsentrat. Sehingga hijaun dan konsentrat yang diberikan pada sapi perah selalu sesuai.

3. Faktor Metode (Method) dengan standard operating procedures dalam pemberian pakan oleh peternak serta peternak menentukan secara pasti kebutuhan hijauan dan konsentrat yang dibutuhkan oleh setiap sapi perah yang dimilikinya.

4. Faktor Lingkungan (Environment) yaitu menghitung suhu yang ada pada kandang secara berkala.

\section{KESIMPULAN DAN SARAN}

Kesimpulan

Berdasarkan hasil penelitian diperoleh beberapa kesimpulan, sebagai berikut:

1. Terdapat data yang berada diluar batas kendali pada peta kendali rata-rata (X) dan tidak terdapat data yang berada diluar batas kendali pada peta kendali jarak (R). Adanya data yang berada diluar batas kendali yang telah ditentukan, maka dilakukan analisis penyebab terjadinya hal tersebut dengan menggunakan diagram sebab akibat (fishbone diagram).

2. Faktor yang digunakan dalam menganalisis penyebab terjadinya kandungan kadar lemak susu yang berada diluar batas kendali adalah faktor manusia, bahan baku, metode, dan lingkungan. Usulan perbaikan diberikan dalam penelitian ini untuk mengurangi adanya kandungan kadar lemak yang berada diluar batas kendali.

\section{Ucapan Terima Kasih}

Terima kasih disampaikan kepada Laboratorium Statistik dan Rekayasa Kualitas, serta Jurusan Teknik Industri dan Fakultas Teknik Universitas Brawijaya atas segala bentuk dukungan dalam keikutsertaan pada kegiatan Seminar Nasional Inovasi dan Aplikasi Teknologi di Industri (SENIATI) 2018 yang diadakan oleh Fakultas Teknologi Industri, Institut Teknologi Nasional Malang.

\section{DAFTAR PUSTAKA}

[1]. Nasution, A.H. 2006. Manajemen Industri. Yogyakarta: Andi Offset. 
[2]. Wignjosoebroto, S. 2003. Pengantar Teknik \& Manajemen Industri. Surabaya: Penerbit Guna Widya.

[3]. KUD Sumber Makmur Ngantang, KUD Sumber Makmur Ngantang, http://kudsumbermakmur.blogspot.co.id/ , diakses pada tanggal 5 September 2017.

[4]. Gasperz, V. 2005. Total Quality Manajemen. Jakarta: PT. Gramedia Pustaka Utama.

[5]. Assauri, S. 1998. Manajemen Produksi dan Operasi. Jakarta: Fakultas Ekonomi Univeristas Indonesia.

[6]. Oakland, J. 2008. Statistical Process Control Sixth Edition. Jakarta: Gramedia.

[7]. Montgomery, DC. 2009. Introduction to Statistical quality Control, $6^{\text {th }}$ Edition. New York: John wiley \& Sons, Inc.

[8]. Arifianti, R. 2013. Analisis Kualitas Produk Sepatu Tomkins. Jurnal Dinamika Manajemen, Vol 4 No. 1, pp. 46-58.

[9]. Hargo, H.D. 2013. Implementasi Metode Pengendalian Kualitas Pada Proses Produksi Tali Rafia Hitam Dengan Menggunakan Metode Statistik Di UD Kartika Platik Jombang. Jurnal Ilmiah Mahasiswa Universitas Surabaya, Vol.2 No.1.

[10]. Tanjong, S.D. 2013. Implementasi Pengendalian Kualitas Dengan Metode Statistik Pada Pabrik Spareparts CV Victory Metalurgy Sidoarjo. Jurnal Ilmiah Mahasiswa Universitas Surabaya, Vol. 2 No.1.

[11]. Ariani, D.W. 2004. Pengendalian Kualitas Statistik (Pendekatan Kuantitatif Dalam Manajemen Kualitas). Yogyakarta: Penerbit Andi.
[12]. Andriani, D.P., Ghazian, T.M.F., "Analisis Assignable Variation Produk Aluminium Florida dengan Statistical Quality Control Method", dalam Indonesia Statistical Analysis Conference (ISAC) 2016, Jurusan Teknik Industri, UNS, pp. 98-107, 8-9 Mei 2017.

[13]. Rustendi, I. 2012. Aplikasi Statistical Process Control (SPC) Dalam Pengendalian Variabilitas Kuat Tekan Beton. Teodolita, Vol. 14, No.1, pp. 1636.

[14]. Montgomery, DC. 2001. Introduction To Statistical Quality Control 6th Edition. Jakarta: PT. Gramedia Pustaka Utama.

[15]. Andriani, D.P., Rizky, D.A., dan Setiaji, U., "Pengendalian Kualitas Kadar Air Produk Kerupuk Udang Berbasis SNI Menggunakan Statistical Quality Control Method", dalam Seminar dan Konferensi Nasional IDEC 2017, Jurusan Teknik Industri, UNS, pp. 98107, 8-9 Mei 2017.

[16]. Gasperz, V. 2002. Metode Analisa untuk Peningkatan Kualitas. Jakarta: Penerbit Gramedia Pustaka Utama.

[17]. Andriani, D.P., Tama, I.P., Sulistyarini, D.H., dan Widi, F.P., " Pengendalian Kualitas Kehalusan Semen PPC $40 \mathrm{Kg}$ Menggunakan Metode Statistical Quality Control", dalam Seminar Nasional Sains dan Teknologi (SAINTEK) 2017, Jurusan Teknik Mesin, UB, pp. 232-241, 7-8 September 2017.

[18]. Purnomo, H. 2004. Pengendalian Kualitas Statistik. Yogyakarta: Penerbit Graha Ilmu 